\title{
CAPACITY OF PROFESSIONAL SPECIALISTS IN RESIDENTIAL HOUSING MANAGEMENT IN LATVIA
}

\author{
Iveta PUKīTEE ${ }^{1}$, Iveta STĀMURE ${ }^{2}$, Ineta GEIPELE ${ }^{3}$ \\ ${ }^{1-3}$ Riga Technical University, Latvia \\ Corresponding author e-mail: iveta.pukite@rtu.lv
}

\begin{abstract}
The issue of residential housing management, depending on the chosen form of the residential housing administration, is topical both from the perspective of residential building apartment owners, if apartment owners have chosen to manage the building themselves, and from the residential house manager's point of view, if the management of the residential building has been entrusted to a professional manager. This is justified by the fact that the process of residential housing maintenance and management is based on knowledge, experience and financial resources; besides, it should be carried out by meeting the existing legislative requirements of the European Union and the Republic of Latvia, as well as the interests of the apartment owners.

In Latvia, in order to manage a residential building, the administrator is required to have appropriate professional education, which, according to the Law of Residential Housing Management, should be at least the $4^{\text {th }}$ level of Professional Qualification accepted in Latvia (the $5^{\text {th }}$ level of European Qualifications Framework, EQK, and Latvian Qualifications Framework, LQK).

The topicality of the study is related to the fact that in Latvia the law stipulates that a residential housing manager should have vocational education, which can be obtained at a number of public educational institutions. In the management process owners can choose their preferred management model, but right now the Register of the Ministry of Economics does not provide full information about the professionalism of an administrator. The goal of the study is determined by the topicality of the theme - to explore the existing models of residential housing management in the Latvian market and professional capacity of specialists involved in management. Within the framework of the study, statistical, qualitative and analytical methods have been used.

As at present in Latvia there is no unified system for the accounting of housing management education in the market, the research results will contribute to its development and creation.
\end{abstract}

Keywords: Education, Professional competence, residential housing manager, residential housing management models.

\section{INTRODUCTION}

The process of residential housing maintenance and management is a timeconsuming, technical and economic knowledge-intensive as well as financial resource-inclusive activity. The issue of residential housing management became topical over the last 20 years, when Latvia experienced the rapid pace of 
privatisation process, the beginning of new housing construction, as well as coming into force of the Law On Administration of Residential Houses on 1 January 2010.

Residential construction is one of the major real estate market segments (Geipele \& Auzin̄š, 2015).

The housing sector affects all levels of the society and is of economic and social nature. Hence, apartment owners, who bear the responsibility for residential building maintenance and management, should decide how to organise the operation and management of residential building as effectively as possible and in compliance with the existing regulations.

Since 1 January 2010 the Residential House Management Law in which the legislator has with-drawn the term "administration" and has retained the term "management" has entered into force. De-fining the terms used in the Law, the definition for the term "administration" is not provided. (Geipele S., Geipele I., Slava, \& Stāmure, 2012)

In the Republic of Latvia, the qualification of professional administrator can be obtained at universities by undertaking either intramural or extramural studies (it is possible to obtain the degree of professional Bachelor and professional qualification that corresponds to the 2 nd level of professional higher education according to the Latvian education system) or at colleges that implement the $1^{\text {st }}$ level professional higher education. In order to ensure the development, competitiveness, employment and social cohesion of industry specialists in the European Community, it is essential to develop and recognise knowledge, skills and competences of personnel. To achieve the development and recognition, transnational mobility of employees and learners should be encouraged and contribution should be made to meet the supply and demand of the European labour market. Therefore, at the national and community levels it is necessary to facilitate and promote the participation in lifelong learning, its availability and use of qualifications obtained (EUR-Lex, 2006).

The article aims to examine the models of residential housing management and administrator's professional capacity necessary to implement the management processes. Within the framework of the study, the following objectives have been set: to make the survey of scientific literature, to examine legal requirements relating to the competences of an administrator, to determine management models and participants, as well as to explore education statistics on administrators' qualification in Latvia. Statistical, qualitative and analytical research methods were used in the study.

\section{THEORETICAL AND LEGAL ASPECTS}

In Latvia, competence standards for administrators are stipulated by the Law on Administration of Residential Houses. Section 13 determines vocational qualifications of the Administrator of a Residential House. A person is entitled to perform the administrative task in an apartment house, if he or she has acquired the vocational education necessary for the administration of residential houses and holds a document certifying at least the $5^{\text {th }}$ level of European Qualifications Framework (EQF) and Latvian Qualifications Framework (LQF) (the $4^{\text {th }}$ level of 
Latvian Professional Qualification), except the cases specified in this Section. If the administrator is a legal person, it is necessary for such employee of the legal person, who performs the administrative task assigned in the administration contract in the relevant house, to have a document certifying the vocational education necessary for the administration of residential houses and at least the $5^{\text {th }}$ level of European Qualifications Framework (EQF) and Latvian Qualifications Framework (LQF) (the $4^{\text {th }}$ level of Latvian Professional Qualification). If the total area of an apartment house exceeds 1500 square metres, it is necessary for the following persons to have a document certifying the vocational education necessary for the administration of residential houses and at least the $4^{\text {th }}$ level of European Qualifications Framework (EQF) and Latvian Qualifications Framework (LQF) (the $3^{\text {rd }}$ level of Latvian Professional Qualification):

1) an owner, who is personally administrating a residential house belonging to him or her;

2) an owner, who has been authorised to perform administrative activities by the other residential house owners on the basis of a mutual contract entered into in accordance with the procedures laid down in the Civil Law;

3) an employee of the administration society of a residential house or association established by the owners, as well as a member of an administration society or association, who performs relevant administrative activities and is a residential house owner himself or herself (Legislation of the Republic of Latvia, 2010).

Professional competence is a set of knowledge, skills and responsibilities required to perform professional activities in a particular work situation. Professional qualification level is theoretical and practical preparedness, which provides an opportunity to perform work corresponding to a certain level of complexity and responsibility (Legislation of the Republic of Latvia, 1999b).

According to the Education Law of the Republic of Latvia, the Latvian Qualifications Framework is in compliance with the European Qualifications Framework. The levels of the Latvian Qualifications Framework are characterised by learning outcomes achieved at a particular level. According to the Law, the $5^{\text {th }}$ level of European Qualifications Framework and Latvian Qualifications Framework (the $4^{\text {th }}$ level of Latvian Professional Qualification) is the ability to demonstrate comprehensive knowledge and independently plan and organise work in the relevant sector, taking responsibility, working independently or in a team, or managing other people's work. The $6^{\text {th }}$ level of European Qualifications Framework and Latvian Qualifications Framework (the $5^{\text {th }}$ level of Latvian Professional Qualification) determines the ability to demonstrate comprehensive and specialized knowledge in the relevant sector; ability to apply analytical skills to solve practical problems in a changing environment of the respective profession; ability to understand the scope of one's activities in a broader social context, take part in the development of the relevant sector, assess one's own and other people's performance (Legislation of the Republic of Latvia, 1999a).

Professional competence is attributed to activities in the work process. It shows the quality of work and continuous efficiency, and remains in case of changes in the organisation's internal and external conditions (Puḳite G., 2014). In recent 
years, the rapid development of legislation has been taking place in the field of real estate, there have been changes in construction norms, and the field of information systems has been rapidly developing as well.

It is widely accepted that the evolution of building information modelling (BIM) is increasingly affecting the roles of construction management professionals in architecture, engineering, and construction (AEC) industry. Since the transition from $2 \mathrm{D}$, drafting to BIM is more of a process transformation, the use of BIM also affects how information is managed by and for construction management professionals. Teaching BIM in construction engineering and management (CEM) curriculum requires more emphasis on learning BIM as a process improvement methodology rather than only a technology (Wang \& Leite, 2014).

The definition of knowledge can vary across disciplines; however, the processes involved in the discovery, capturing, sharing, and application of the knowledge will still be present. These processes of working with knowledge are not new to businesses, but with innovations within information systems, the ability to conduct these processes has provided organisations with new opportunities to manage the knowledge (Little, 2011).

It is also the responsibility of each organisation to assign value to its knowledge. This value can then dictate how an organisation accepts knowledge as intellectual asset. Given the new aspects of how knowledge can be obtained, new knowledge will more likely be created through technological innovations rather than manual or historically traditional methods (Little, 2011).

Knowledge - the focus in business and in the overall economy at large is towards tapping the huge resource of human capital, easily translated into knowledge. In the new economy, knowledge is the driver and other traditional resources are secondary. With knowledge power comes and a way to change life for the better through newer opportunities. This means that organisations will be forced to change their old opinion of employees and try to retain and develop the capabilities of knowledge workers (Tapscott, 1996).

The main purpose of the educational work is the training of creative thinking and harmoniously developed specialists with profound theoretical knowledge, formed professional competence and high moral qualities (Vēbers, 2011).

Socially responsible approach to the management of Latvian enterprises is becoming increasingly important, especially in the development of corporate culture of medium-sized and large enterprises.

Following today's development trends of society, market and corporate governance, there is an evident tendency towards integration of responsibility and value in various processes and areas. Human resources are one of a company's key elements and success factors that often make up the company's competitive advantage. (Lapiṇa, Maurāne, \& Starineca, 2013)

In Latvia, according to Section 10 of the Law On Administration of Residential Houses, a residential house owner may assign all or individual activities of administration of a residential house to be performed by an administrator (Legislation of the Republic of Latvia, 2010).

There are different models of residential housing management. Apartment owners decide which model of residential housing management to choose. 
Along with the privatisation of apartments, the responsibility for the maintenance of residential buildings is undertaken by apartment owners; however, the owners' understanding of property maintenance is still limited. After the privatisation of residential buildings, apartment owners themselves had the opportunity to decide on the "destiny" of the apartment and residential building, i.e., the right to choose the management and maintenance procedure, to determine the quality of their lives and the efficient use of their resources.

This means that the apartment building owners have only two options - either to manage the residential building themselves or assign its management to another person - administrator. If a decision is made to entrust the management of the residential house to an administrator, the contract on the administration of the residential building should be concluded. The residential building management can be entrusted to a natural entity, a legal entity established by apartment owners cooperative society of apartment owners, an association of apartment owners or a company that provides management services (Puķīte, 2010).

\section{DISCUSSIONS AND RESULTS}

The residential housing management process and the opportunities of its organisation can be presented schematically (see Fig. 1).

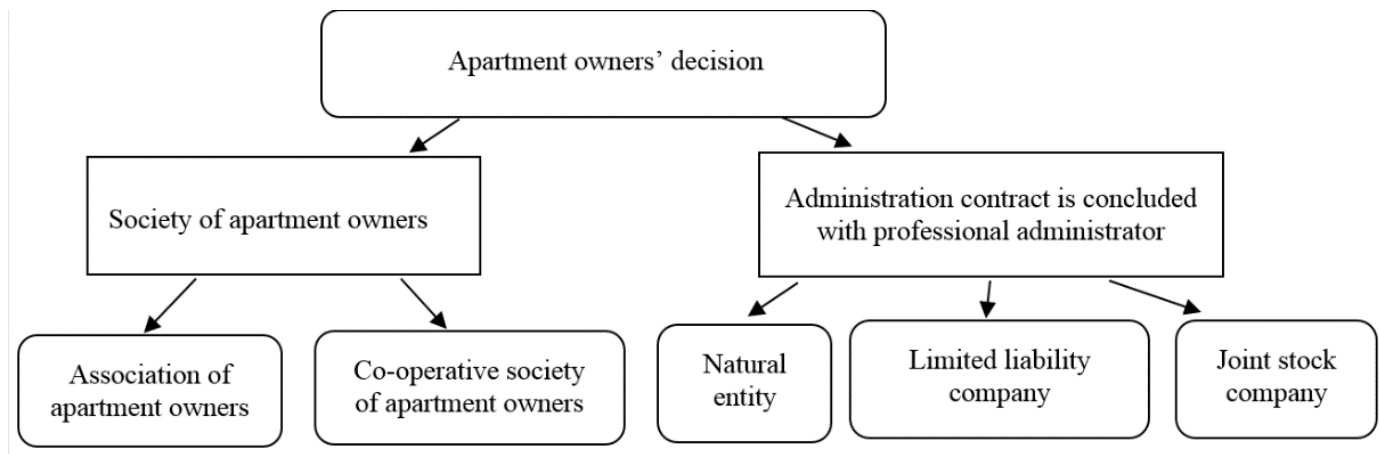

Fig. 1. The process of residential housing management and its organisation [developed by the authors].

As shown in Fig. 1, joint estate management may take various forms - it is possible to entrust residential building management either to a professional administrator, which most often is a limited liability company or to the community of apartment owners by establishing the association of apartment owners or cooperative society of apartment owners.

At present, there are two main directions in Latvia.

The first direction: Administration service provider works at a municipal company. It is substantiated by the Law On Privatisation of State and Local Government Residential Houses, which states that the state residential house owner or the local government is obliged to manage a residential house until transfer of the management rights to the society of apartment owners or a person authorised 
by the apartment owners on the basis of mutual agreement, if not all objects in a residential building are privatised.

The residential house owner or local government is responsible for residential building management even if all objects in a residential building are privatised, but a general meeting of apartment owners is not convened (Legislation of the Republic of Latvia, 1995).

Consequently, still a lot of residential houses are managed by the local government on the legitimate basis. Reasons and situation retention arguments are both at the owners' and local government side. Apartment owners do not want to participate in the management process, there is a lack of knowledge and poor mutual trust. In recent years, trends in housing management have led to negative consequences - private administration companies go bankrupt followed by loss of financial resources paid by owners. Therefore, at present the municipal companies ensure greater financial security. These companies require the administrators to have professional management education.

The second direction: Private specialised housing administration and management companies, construction and new project development companies, real estate companies or their departments work with housing management. Private companies should bring new positive trends in the housing management market since the competition promotes the development of the sector and regulates the service price. Housing management services should develop on the basis of a longterm relationship, but in practice there are cases where entrepreneurs who focus on the short-term cash flow aggressively operate in the market and in the end undergo insolvency.

As of 1 September 2016, in the Register of Administrators of Residential Houses maintained by the Ministry of Economics there were recorded 644 specialists, who had at least one contract for house administration and the right to manage the property (Ministry of Economics, n.d.). However, the information collected by the informative business inquiry service ZL.LV demonstrates that there are 580 companies of different size offering housing management services in Latvia (ZL.LV, n.d.).

Associations or co-operative societies represent the housing management form that is implemented by house owners or apartment owners of several houses, who take their property over from the state or local government and perform planned property management, maintenance and development. It is relatively seldom that associations or co-operative societies take over the management of the residential buildings, because in the situation of the existing Latvian regulatory framework, bad experience, negative reputation of administrators, and negative attitude of neighbours, a house activist has little motivation to undertake the management process.

An association is a voluntary union of persons founded to achieve the goal specified in the articles of the association, which does not have a profit-making nature (Legislation of the Republic of Latvia, 2004).

As demonstrated by the data collected by the informative business inquiry service ZL.LV, which have been aggregated by the authors of the paper in Fig. 2, there are 655 apartment owner associations registered in Latvia. Their division by regions is as follows: 397 associations are located in Riga, 222 - in Kurzeme, 7 - 
in Latgale, 15 - in Vidzeme and 8 - in Zemgale (authors' calculations based on the available data) (ZL.LV, n.d.).

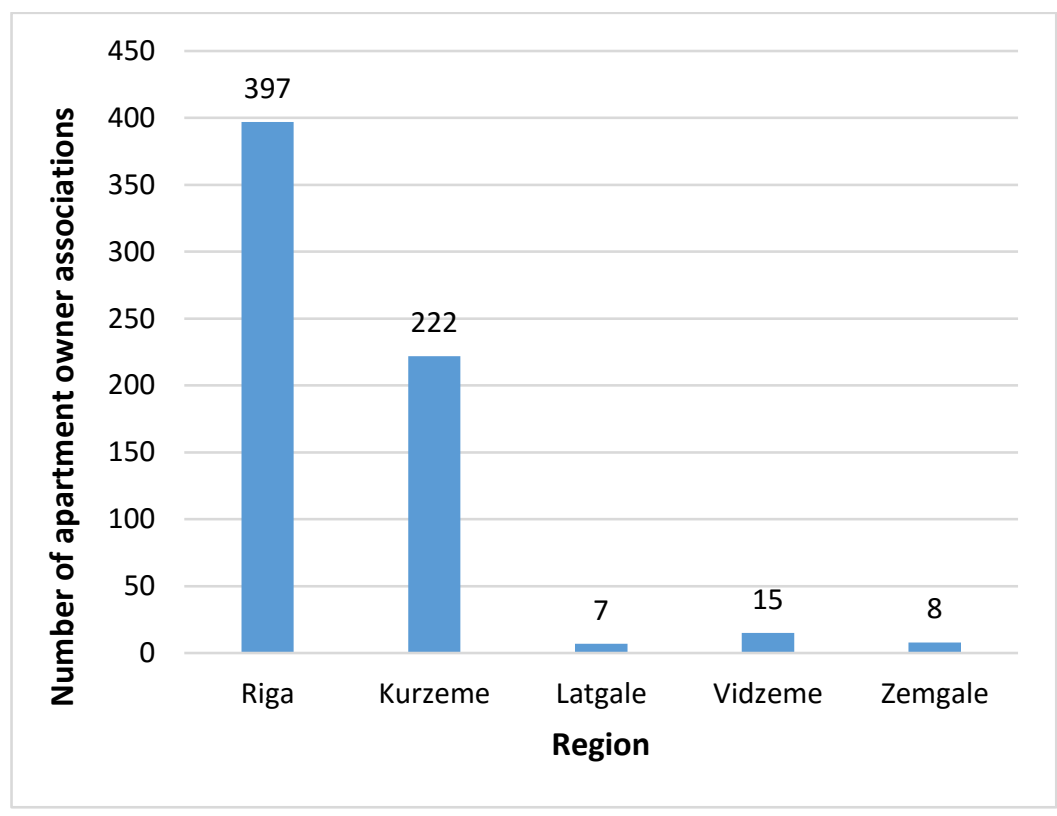

Fig. 2. The number of apartment owner associations in Latvia [developed by the authors].

A co-operative society shall be a voluntary organisation in which any natural person and legal person with the capacity to act may join without any social, gender, political and religious discrimination if such a person wishes to receive the services of this organisation and to undertake its membership duties in conformity with the articles of association of the society. The activity of a co-operative society shall be managed by its members, by actively and democratically participating in the management of the society (Legislation of the Republic of Latvia, 1998).

There are 269 co-operative societies of apartment owners registered in Riga, whose contact information is available in the catalogue of the informative business inquiry service ZL.LV. The number of co-operative societies registered in Kurzeme is 21 , in Vidzeme - 37, in Zemgale - 23 (17 of them in Jelgava). In Latgale 47 cooperative societies are registered ( 8 of them are located in Daugavpils, 16 - in Jekabpils, 7 - in Kraslava, 1 - in Preili and 15 - in Rezekne). In total there are 397 cooperative societies of apartment owners registered in Latvia (the authors' calculations based on the data available), see Fig. 3. (ZL.LV, n.d.).

In Lursoft database under NACE code 68.32 "Management of real estate on a fee or contract basis" 4317 legal entities engaged in real estate management are registered (Lursoft, n.d.).

In the division of residential buildings, by the main type of use in Latvia, the highest share belongs to single-family houses -306295 or $85.10 \%$ of the number of houses registered in the Cadastre Information System. In the second place come three-or-more-family dwellings or multi-family houses that account for 39459 or $10.96 \%$. In the Cadastre Information System, there are only 13473 (or $3.74 \%$ ) of 
two-family houses registered, thus, in Latvia these houses are less frequently met, but the share of houses shared for living by various social groups is only 670 or $0.186 \%$ (see Table 1) (State Land Service, 2016).

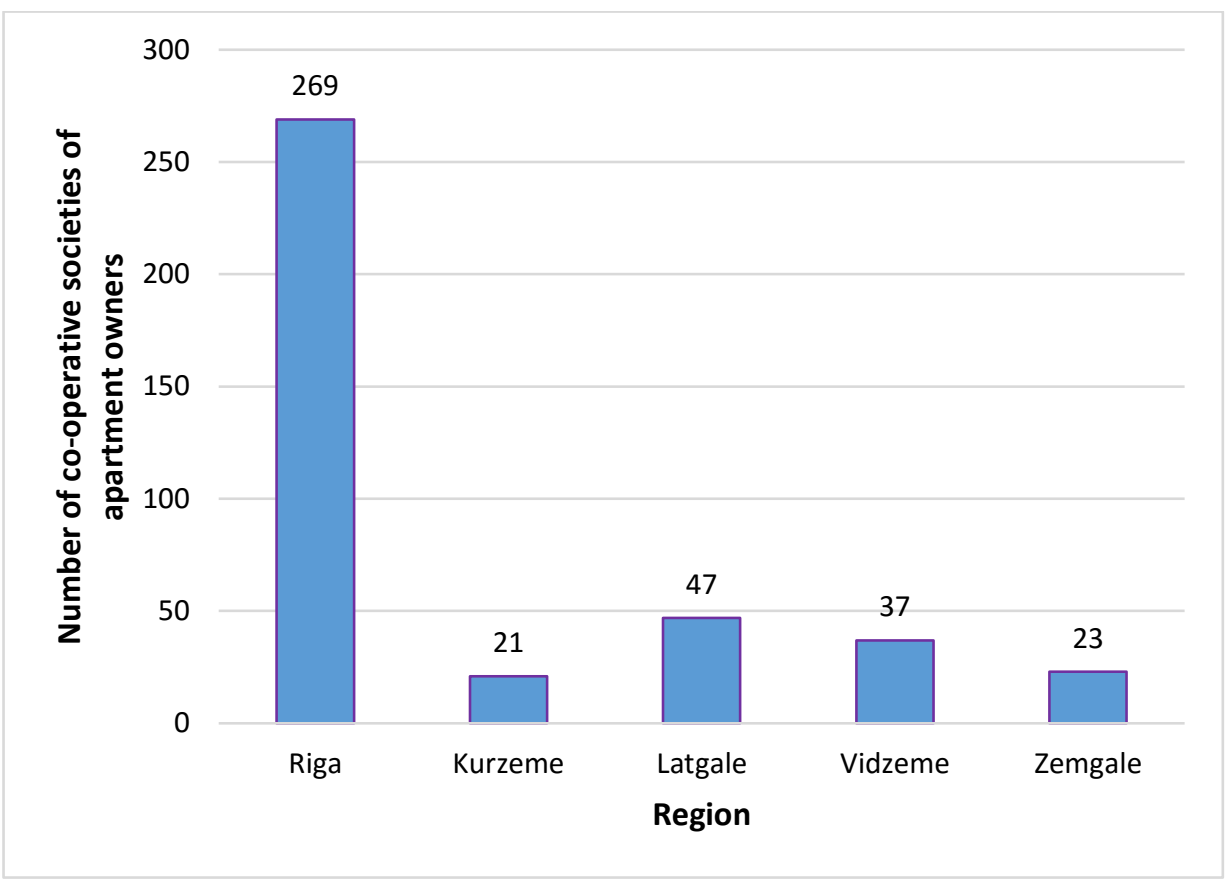

Fig. 3. The number of co-operative societies of apartment owners in Latvia [the authors' calculations].

Table 1. The Division of Residential Buildings by Main Type of Use in Latvia, as of 1 January 2016 (State Land Service, 2016)

\begin{tabular}{|c|c|c|}
\hline Main type of use & $\begin{array}{c}\text { Number of } \\
\text { buildings } \\
\text { constructions) }\end{array}$ & $\begin{array}{c}\text { \% of the total } \\
\text { number of } \\
\text { constructions }\end{array}$ \\
\hline Single-family houses & 306805 & 85 \\
\hline Two-family houses & 134751 & 3.8 \\
\hline Three-or-more-family houses & 39459 & 11 \\
\hline $\begin{array}{c}\text { Houses shared for living by various social } \\
\text { groups }\end{array}$ & 6763 & 0.2 \\
\hline Total residential buildings & $\mathbf{4 8 7} \mathbf{7 7 8}$ & $\mathbf{1 0 0}$ \\
\hline
\end{tabular}

Within the framework of the research, special attention is devoted to three-ormore-family residential buildings, as well as houses shared for living by various social groups, because they are classified as multi-family residential buildings, to which professional administrators are assigned. The given housing group constitutes a total of 46222 objects that should be managed. 
From the above-mentioned information, it is assumed that in Latvia there are 46222 multi-family residential buildings managed by 4317 legal entities that have registered their activity in the field of real estate management and maintenance. On average, there are 10.7 residential buildings to be managed by a single legal entity that has registered its activity in the Register of Enterprises (the authors' calculations based on the information available at Lursoft database).

However, summarising the information on active legal entities that is made available in informative business inquiry service ZL.LV, it should be concluded that there are 1901 legal entities engaged in the provision of management and maintenance services in Latvia. Thus, it can be concluded that on average there are 24 multi-family residential buildings per single legal entity (the authors' calculations based on the data available).

Comparing the obtained results with the information provided in the Register of Enterprises of the Republic of Latvia one can find a discrepancy; there are 4317 legal entities registered in the Register of Enterprises (Lursoft, n.d.), while according to different informational catalogues services are provided only by 1901 legal entities (the authors' calculations based on the available data).

The number of administrators of multi-family residential buildings that is needed in order to conduct the survey can be found out using the data of the Register of Administrators of Residential Houses.

The Law On Administration of Residential Houses regulates that any person who conforms to the requirements stipulated in this Law for an administrator and has entered into an administration contract with the residential house owner, as well as a society or association established by apartment owners, which on the basis of a decision of the body corporate of apartment owners administers the residential house itself, shall be registered in the Register of Administrators within one month after entering into the administration contract, by submitting the documents specified in this Law to an official of the Register (Legislation of the Republic of Latvia, 2010).

It should be noted that in Latvia the amount of work per administrator is not determined. In practice, the amount of work is determined by companies on the basis of different assessment scales. The amount of work is determined by the manageable area, number of property objects, technical condition of a building, the degree of construction complexity. The management portfolio for large companies is divided according to zoning: by cities, villages, regions; in Riga - according to the suburb distribution.

In Latvia, there are several education institutions, where it is possible to obtain education and qualification of a house manager. Using telephone interviews, the authors have found out that not all education institutions are willing to make public the number of persons who have obtained the $4^{\text {th }}$ level of European Qualifications Framework and Latvian Qualifications Framework (the $3^{\text {th }}$ level of Latvian Professional Qualification); therefore, three training centres have not been included in the study. The obtained data are demonstrated in Table 2. 
Table 2. The Number of House Managers with the $4^{\text {th }}$ Level of European Qualifications Framework and Latvian Qualifications Framework (the $3^{\text {th }}$ Level of Latvian Professional Qualification) [the authors' calculations]

\begin{tabular}{|c|c|}
\hline Education institution & Number of persons \\
\hline Training centre "B" & 311 \\
\hline Training centre "P" & 179 \\
\hline Training centre "L" & 10 \\
\hline College of Law & 108 \\
\hline Total & 608 \\
\hline
\end{tabular}

As of 3 January 2016, a total of 608 persons have obtained the $4^{\text {th }}$ level of European Qualifications Framework and Latvian Qualifications Framework (the $3^{\text {rd }}$ level of Latvian Professional Qualification) in Latvia.

Table 3 summarises the information on the number of natural and legal entities (administrators and managers) and the appropriate qualification on the basis of the Register of Administrators of Residential Houses of the Building Information System (BIS) maintained by the Ministry of Economics of the Republic of Latvia.

Table 3. The Qualification Level of Professional Administrators Included in the Register of Administrators of Residential Houses (Ministry of Economics, n.d.)

[Made by the authors on the basis of the Building Information System]

\begin{tabular}{|c|c|c|}
\hline Qualification level & $\begin{array}{c}\text { Qualification level of } \\
\text { natural entities }\end{array}$ & $\begin{array}{c}\text { Qualification level } \\
\text { of legal entities }\end{array}$ \\
\hline Qualification level is not determined & 2 & 1 \\
\hline $\begin{array}{l}\text { The } 4^{\text {th }} \text { level of European } \\
\text { Qualifications Framework and Latvian } \\
\text { Qualifications Framework (the } 3^{\text {rd }} \\
\text { level of Latvian Professional } \\
\text { Qualification) }\end{array}$ & 163 & 239 \\
\hline $\begin{array}{l}\text { The } 5^{\text {th }} \text { level of European } \\
\text { Qualifications Framework and Latvian } \\
\text { Qualifications Framework (the } 4^{\text {th }} \\
\text { level of Latvian Professional } \\
\text { Qualification) }\end{array}$ & 46 & 60 \\
\hline $\begin{array}{l}\text { The } 6^{\text {th }} \text { level of European } \\
\text { Qualifications Framework and Latvian } \\
\text { Qualifications Framework (the } 5^{\text {th }} \\
\text { level of Latvian Professional } \\
\text { Qualification) }\end{array}$ & 27 & 56 \\
\hline Total: & 238 & 356 \\
\hline
\end{tabular}

After examining the data provided in the Register of Administrators of Residential Houses, it has been concluded that they are incomplete as only a small number of administrators has been registered. The system is currently being evaluated as incomplete also from the reliability point of view because using the 
data demonstrated in Table 3 it is not possible to determine the precise number of administrators due to the fact that at present the data registered under legal entities can duplicate with the data on natural entities. This means that at the moment the data on the number of educated and trained specialists overlap. Moreover, the Register does not provide the information on the number of residential houses managed by the entities included in the Register. The BIS register of the Ministry of Economics is set up on legitimate basis, but it is currently of informative nature, which implies that it does not include a mandatory requirement to register.

The Law on Administration of Residential Housing does not envisage any adverse legal consequences if the mentioned entities are not registered in the Register, i.e., non-registration does not affect either the validity of the administration contract or the scope of administrator's responsibility stipulated by the law (Ministry of Economics, n.d.).

The Association of House Administrators and Managers of Latvia unites 40 legal entities - the largest real estate administration and management companies, and 6 natural entities (The Association of House Administrators and Managers of Latvia, 2016).

The Latvian House Managers Guild brings together natural entities which are engaged in real estate management. The list comprises 107 natural entities. However, also in this case the available information is incomplete because, as the data show, the records were updated in 2013 (The Association of House Administrators and Managers of Latvia, 2016).

According to the legislation, most of the administrators should have at least the $5^{\text {th }}$ level of European Qualifications Framework and Latvian Qualifications Framework (the $4^{\text {th }}$ level of Latvian Professional Qualification). In Latvia, there are four higher education institutions where students can obtain the qualification of House Manager (the $5^{\text {th }}$ level of European Qualifications Framework and Latvian Qualifications Framework (the $4^{\text {th }}$ level of Latvian Professional Qualifications)). These are Riga Technical University, College of Law, Jekabpils Agrobusiness College, Riga International School of Economics and Business Administration (RISEBA).

In Table 4, the authors provide information on the total number of house managers in Latvia, who have the $5^{\text {th }}$ level of European Qualifications Framework and Latvian Qualifications Framework (the $4^{\text {th }}$ level of Latvian Professional Qualification). The College of Law launched its study programme in the academic year 2005/2006. The largest number of graduates comes from the College of Law. It can be explained by the fact that at the College of Law it is possible to acquire only the $1^{\text {st }}$ level higher education, which recently has become very popular in Latvia. Having obtained the education, large number of students continue their studies at Riga Technical University, with which the College of Law has signed a cooperation agreement on student enrolment in the $3^{\text {rd }}$ year of Bachelor's study programme.

According to the calculations (see Table 4) performed by the authors of the study, there are 444 professionals in Latvia who have the $5^{\text {th }}$ level of European Qualifications Framework and Latvian Qualifications Framework (the $4^{\text {th }}$ level of 
Latvian Professional Qualification) in the field of house administration and management.

Table 4. The Number of House Managers with the $5^{\text {th }}$ Level of European Qualifications Framework and Latvian Qualifications Framework (the $4^{\text {th }}$ Level of Latvian Professional Qualification), the situation as of 1 July 2016 [the authors' calculations]

\begin{tabular}{|l|c|}
\hline \multicolumn{1}{|c|}{ Education institution } & \multicolumn{1}{|c|}{$\begin{array}{c}\text { Number of } \\
\text { persons }\end{array}$} \\
\hline Riga Technical University & 32 \\
\hline Jekabpils Agrobusiness College & 24 \\
\hline College of Law & 348 \\
\hline $\begin{array}{l}\text { Riga International School of Economics and Business } \\
\text { Administration }\end{array}$ & 40 \\
\hline \multicolumn{1}{|c|}{ Total } & $\mathbf{4 4 4}$ \\
\hline
\end{tabular}

Riga Technical University provides the possibility of obtaining a professional Bachelor's degree in real estate management and one of the 6 levels of EQF and LQF specialisations in real estate. The following qualification can be obtained: Real Estate Manager, Real Estate Appraiser, and Real Estate Economist. The study programme was launched in the academic year 2005/2006. In the third year of studies, students have to choose specialisation. In Table 5 the authors of the research provide the information obtained after interviewing the administration of professional Bachelor's study programme "Real Estate Management".

Table 5. The Number of Graduates at RTU of the Professional Bachelor's Study Programme "Real Estate Management", situation as of 1 July 2016 [made by the authors]

\begin{tabular}{|c|c|c|c|}
\hline \multicolumn{4}{|c|}{ Professional qualification, the number of graduates } \\
\hline Total & $\begin{array}{c}\text { Real Estate } \\
\text { Economist }\end{array}$ & Real Estate Manager & $\begin{array}{c}\text { Real Estate } \\
\text { Appraiser }\end{array}$ \\
\hline 436 & 93 & 262 & 81 \\
\hline
\end{tabular}

From analyses of the information provided in Table 5, it should be concluded that most of the graduates have chosen the qualification of Property Manager. Out of the total number of graduates $436.61 \%$ or 262 graduates have obtained the qualification of Real Estate Manager, $21 \%$ or 93 graduates have the qualification of Real Estate Economist and $18.6 \%$ or 81 are Real Estate Appraisers.

If the results are compared with the Register of Administrators of Residential Houses, where it is stated that only 56 legal entities have the $6^{\text {th }}$ level of European Qualifications Framework and Latvian Qualifications Framework, it can be concluded that 206 graduates who have the respective education have not registered in the Register. 
Summarising the above-mentioned information, it can be concluded that there is a wide range of opportunities in Latvia to obtain the appropriate education, and it is possible to undertake the studies gradually.

The main goal of the professional educational work is training of creative thinking and harmoniously developed specialists with profound theoretical knowledge, professional competence and high moral qualities (Kamalova, 2016).

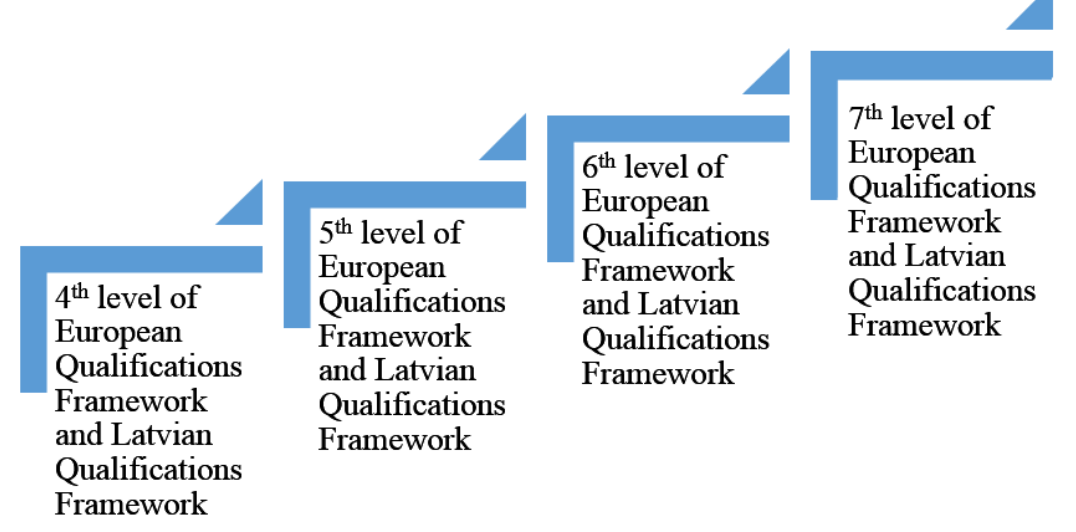

Fig. 4. Education ladder [made by the authors].

As can be seen in Fig. 4, the level of professionalism can be raised by taking the education ladder - starting with the $4^{\text {th }}$ level of European Qualifications Framework and Latvian Qualifications Framework (the $3^{\text {rd }}$ level of Latvia Professional Qualification), which although providing minimal insight into the profession of house manager, still allows one to manage one's own property. The next step is the $5^{\text {th }}$ level, where it is possible to obtain higher education and act as a professional in management industry. But for those students who are willing to widen their horizon and complete higher education, thus being able to undertake Master studies, there is the $6^{\text {th }}$ level of European Qualifications Framework and Latvian Qualifications Framework (the $5^{\text {th }}$ level of Latvian Professional Qualifications), which can be obtained by the students with a Bachelor's degree.

\section{CONCLUSION}

The $1^{\text {st }}$ level of higher education in the field of real estate management attracts both employees who are planning to work as house managers and employers because in a short period of time (two years) it is possible to obtain the first level of higher professional education and the professional qualification of House Manager, which enables one to compete in the labour market. Collaboration among education institutions enables students to continue their studies at the university, which offers the opportunity to obtain both Bachelor's and Master's degree in Real Estate Management. The importance of the respective education is associated with factors such as development of knowledge and skills in the process of real estate management, as well as strengthening and systemising of psychological skills, 
which are essential for employees in this sector. The knowledge acquired in the study process is approbated and strengthened in practice.

There are 39459 three-or-more-family residential buildings in Latvia (State Land Service, 2016), which constitute $10.96 \%$ of the total housing stock to be administered and managed. There is no legislative document that indicates the number of houses that is allowed to be managed by one professional administrator in order to ensure that the work is performed as efficiently as possible.

The research has demonstrated that the administrator can be both the society established by apartment owners and any legal or natural entity. In any case, the administrator should have the appropriate professional competence or qualification level.

Professional competence is a pre-condition that allows achieving excellent results in difficult circumstances; in addition, it is developed in the process of continuous professional activity and affected by the acquired and accumulated experience.

The Register of Administrators of Residential Houses is an information register, the main task of which is to provide updated information on persons who are engaged or willing to engage in residential housing management and meet the criteria stipulated in the Law on Administration of Residential Houses in order to perform management activities. However, the present study has revealed that the Register does not contain full information about the persons who have obtained professional education and offer their services in the area of housing management. It does not provide property owners with a high-quality information on administrators able to evaluate their professional activities with due care. The legislation also does not provide any form of sanctions in cases when administrators manage at least one property without being registered in the Register.

It is necessary to create a unified and systematic registration system of real estate administrators in Latvia that would enable collecting comprehensive information on professional administrators to be able to evaluate their professionalism, competence and due care.

\section{REFERENCES}

EUR-Lex. (2006). Eiropas Parlamenta un Padomes ieteikums par Eiropas kvalifikāciju ietvarstruktūras izveidošanu mūžizglītībai [Recommendation of the European Parliament and of the Council on the establishment of the European Qualifications Framework for lifelong learning]. Eiropas Savienības Oficiālais Vēstnesis [Official Journal of the European Union]. Retrieved June 19, 2016, from https://ec.europa.eu/ploteus/sites/eac-eqf/files/broch_lv.pdf

Geipele, S., \& Auziņš, A. (2015). The Development of Housing Sector and Residential Real Estate Market after Economic Recession in Latvia. Baltic Journal of Real Estate Economics and Construction Management, 3, 103-119. http://dx.doi.org/10.1515/bjreecm-2015-0011

Geipele, S., Geipele, I., Slava, D., \& Stāmure, I. (2012). Social, Economic and Legal Problems of Housing Management in Latvia. In The $7^{\text {th }}$ International Scientific Conference "Business and Management 2012”: Selected Papers, (pp. 631-638). Lithuania, Vilnius, 10-11 May, 2012. Vilnius: VGTU Press "Technika". http://dx.doi.org/10.3846/bm.2012.082

Lapiṇa, I., Maurāne, G., \& Starineca, O. (2013). Aspects of Corporate Social Responsibility and Creating Shared Value: Stakeholders and Human Resources. Economics and Business, 24, 4656. http://dx.doi.org/10.7250/eb.2013.006 
Latvijas Namu pārvaldnieku un apsaimniekotāju asociācija [The Association of House Administrators and Managers of Latvia]. (n.d.). Retrieved March 14, 2016, from http://sharex.lv/sites/default/files/presentations/lnpaa_lps_30032016.pdf

Legislation of the Republic of Latvia. (1995). Par valsts un pašvaldību dzīvojamo māju privatizāciju [On Privatisation of State and Local Government Residential Houses]. Retrieved August 25, 2016, from http://likumi.lv/doc.php?id=35770

Legislation of the Republic of Latvia. (1998). Kooperatīvo sabiedrību likums [Co-operative Societies Law]. Retrieved March 12, 2016, from http://likumi.lv/doc.php?id=47009

Legislation of the Republic of Latvia. (1999a). Izglìtības likums [Education Law]. Retrieved August 28, 2016, from http://likumi.lv/ta/id/50759-izglitibas-likums

Legislation of the Republic of Latvia. (1999b). Profesionālās izglìtības likums [Vocational Education Law]. Retrieved August 28, 2016, from http://likumi.lv/doc.php?id=20244

Legislation of the Republic of Latvia. (2004). Biedrību un nodibinājumu likums [Associations and Foundations Law]. Retrieved March 12, 2016, from http://likumi.lv/ta/id/81050-biedribu-unnodibinajumu-likums

Legislation of the Republic of Latvia. (2010). Dzīvojamo māju pārvaldī̌sanas likums [Law On Administration of Residential Houses]. Retrieved February 2, 2016, from http://likumi.lv/ta/id/193573-dzivojamo-maju-parvaldisanas-likums

Little, T. A. (2011). Knowledge, Intellectual Capital, and Protection: A Literature Review. Proceedings of the $44^{\text {th }}$ Hawaii International Conference on System Sciences. http://dx.doi.org/10.1109/HICSS.2011.278

Lursoft. (n.d.). Uzñēmumu saraksts. [List of companies]. Retrieved March 15, 2016, from http://nace.lursoft.lv/68.32/nekustama-ipasuma-parvaldisana-par-atlidzibu-vai-uz-ligumapamata/companies/

Kamalova, L. A., \& Raykova, E. (2016). The quality and criteria of evaluation of educational work at the universities of Russia at the contemporary stage. IEJME-Mathematics Education, 11(1), 71-79.

Ministry of Economics. (n.d.). Retrieved March 11, 2016, from https://www.em.gov.lv/lv/ Pārvaldnieku reǵistrs. [Register of Administrators]. Retrieved March 15, 2016, from https://bis.gov.lv/bisp/lv/house_managers

Puķīe, G. (2014). Teacher's Professional Competences Improvement in the Pre-School. The Humanities and Social Sciences, 22, 27-35.

Puḳīe, I. (2010). Pārvaldīšanas formas izvēlē daudzdzīvokḷu dzìvojamās mājās. [Management Choice form of Residential Housing]. Pārvaldnieks. Retrieved September 17, 2016, from https://ortus.rtu.lv/science/en/publications/14058/fulltext.

Tapscott, D., (1996). The Digital Economy: Promise and Peril in the Age of Networked Intelligence. NewYork, NY: McGraw-Hill. Retrieved from http-server.carleton.ca

Valsts Zemes dienests [State Land Service]. (2015). Latvijas Republikas būvju pārskats 2015. [Latvian Republic of buildings overview 2015]. Retrieved September 15, 2016, from http://www.vzd.gov.lv/files/buvju_parskats_2015_a552e.pdf

Vēbers, E. (2011). Izglītības vadītāja amata pretendenta kvalifikācija un kompetence. [Education Head of the applicant's qualifications and competence]. Zinātnisko rakstu kopsavilkumu krājums un rakstu krājums CD formātā. Apvienotais Pasaules latviešu zinātnieku 3. kongress un Letonikas 4. kongress Izglītība izaugsmei: pagātne, tagadne un nākotne. Rīgā 2011. gada 24.27. oktobrī.

Wang, L., \& Leite, F. (2014). Process - Oriented Approach of Teaching Building Information Modeling in Construction Management. Journal of Professional Issues in Engineering Education and Practice, 140(4). http://dx.doi.org/10.1061/(ASCE)EI.1943-5541.0000203

ZL.LV. (n.d.). Biznesa uzzinu serviss [Business information service]. Retrieved March 19, 2016 from http://katalogs.zl.lv/ 


\section{AUTHORS' SHORT BIOGRAPHIES}

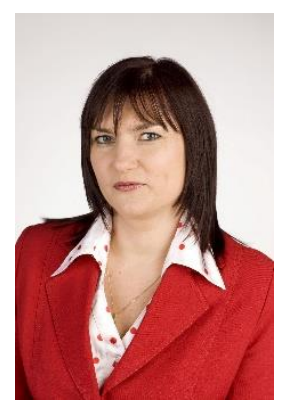

Iveta Puḳite, Mg. sc. ing., is a researcher with the Faculty of Engineering Economics and Management, Riga Technical University, as well as a $\mathrm{PhD}$ student with RTU. Iveta Puḳīe acquired Academic Master's degree in management sciences. She is a Lecturer at the College of Law. Currently she is head of Real Estate Management Department at Ltd. Ādažu Namsaimnieks. She participated in International Scientific Conference "Economic Science for Rural development" in Jelgava; the $3^{\text {rd }}$ European Interdisciplinary Forum 2015 (EIF 2015): "Drivers for Progress in the Global Society" in Vilnius, Lithuania, and others. Her main research theme is socially responsible housing lifecycle of the management system.

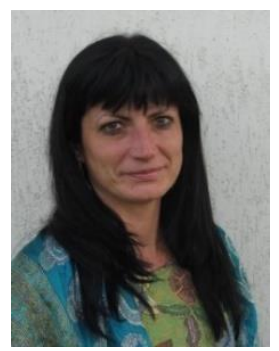

Iveta Stāmure is a $\mathrm{PhD}$ student and a researcher with the Faculty of Engineering Economics and Management, Riga Technical University. She obtained Professional Master degree in civil construction and real estate management with distinction and the qualification of Real Estate Manager. Her main research areas are sustainability development problems of real estate market and construction industry, including land use management and institutional economics. In 2013 she was RTU Gold Fund graduate in 2013 and FIABCI (International Real Estate Federation) grantee.

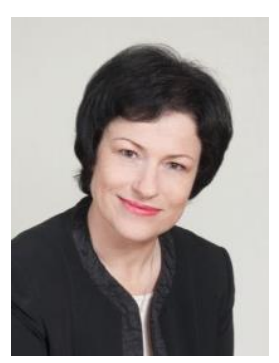

Ineta Geipele is a Professor with the Faculty of Engineering Economics and Management, Director of the Institute of Civil Engineering and Real Estate Economics, Head of the Chair of Civil Construction and Real Estate Economics and Management, Riga Technical University (RTU), Latvia. She obtained Doctor's degree in economics and Master's degree in economics in engineering sciences from RTU. She improved her professional skills in Austria, Germany, Denmark and England. She is an author and co-author of more than 284 scientific publications. Her current research areas are sustainability development problems of real estate market, construction industry, land use management and institutional economics. She is an expert on management science of the Latvian Council of Science, a board member of the FIABCI-Baltic Multinational Chapter, Cunfte of the Facility Management of Latvian Housing and a member of the Latvian Union of Civil Engineers.

ORCID iD: http://orcid.org/0000-0002-2963-087X 